\title{
Factors Influencing Medical Student'S Satisfaction on Online Learning During Covid-19 Pandemic
}

\author{
Artha Budi Susila Duarsa ${ }^{1 *}$, Dina Qurratu Ainin ${ }^{1}$, Dasti Anditiarina ${ }^{1}$ \\ ${ }^{l}$ Faculty of Medicine, Al-Azhar Islamic University \\ *Corresponding author. Email: arthasusiladuarsa@gmail.com
}

\begin{abstract}
Education has been affected by the COVID-19 pandemic. The pandemic causes banned access to schools and universities. The students are moving into online learning from the conventional learning. This study aimed to analyze the factors influencing the satisfaction of medical students on online learning during the pandemic of COVID-19. This was a cross-sectional study at the Al-Azhar Islamic University, Mataram, West Nusa Tenggara. A total of 260 medical students was enrolled in this study. The dependent variable was online learning satisfaction. Independent variable were knowledge, attitude, and perception. Data were collected using questionnaire and analyzed using multiple logistic regression. High knowledge $(\mathrm{OR}=1.94 ; 95 \% \mathrm{CI}=1.07$ to $3.51 ; \mathrm{p}=0.029)$, positive attitude $(\mathrm{OR}=1.96 ; 95 \% \mathrm{CI}=1.08$ to $3.55 ; \mathrm{p}=0.026)$, and positive perception $(\mathrm{OR}=7.02 ; 95 \% \mathrm{CI}=3.90$ to $12.63 ; \mathrm{p}<0.001)$ increased the positive medical student's satisfaction towards online learning during pandemic COVID-19. Medical student's satisfaction during pandemic COVID-19 increases by high knowledge, positive attitude, and positive perception. The university needs to provide a good online learning environment to increase medical student's satisfaction.
\end{abstract}

Keywords: satisfaction, student, online learning.

\section{INTRODUCTION}

Indonesian government in overcoming the spread of the corona virus disease (COVID-19), made a policy called PSBB. It is to lock down, especially in the red zone area of the high distribution/cases of COVID-19. Lock down has a major impact on changes in the learning system in the world of education, where usually in classrooms with face-to-face methods turn into online learning or virtual learning. The online learning system requires students and teachers to maximize the potential of the internet in communicating or accessing learning materials via social media platforms [1].

Online learning system has its own weaknesses and strengths. As the advantage, online learning train students to become independent individuals to make the most of the internet network in accessing learning material without any time limit whenever and wherever they are so that it fosters the hidden potential in them, especially for students who are smart or potential but antisocial or introverted. One of the weaknesses felt by students in the new online learning system during the pandemic was weak internet connection or the exhaustion of provider network quota, especially for students from rural areas whose internet network access was still weak [2].
This study about the relationship of online teaching processes with the level of student satisfaction was carried out during the COVID-19 pandemic. This was done to see how students react and adaptation levels to new learning processes from what is usually face-to-face to an online system. According to Basid et al. (2020) there is a specific relationship between online learning and academic values or abilities where students are able to adapt well to changes in the online learning system [3].

Some factors were contributed in increasing the student's satisfaction in online learning during COVID19 pandemic. Specific learning objectives also have an important role in student learning satisfaction because they have a major impact on student satisfaction in online learning [4,5]. It is one of good indicators for assessing the quality and effectiveness of online learning. It is important for institutions to know whether their students are satisfied with their learning experience in general. So, this study was conducted to examine the factors influencing the satisfaction of medical students on online learning during the pandemic of COVID-19. 


\section{SUBJECTS AND METHOD 2.1 Study Design}

This was a cross-sectional study carried out in JulyAugust 2020 at Faculty of Medicine, Al-Azhar Islamic University, Mataram, West Nusa Tenggara, Indonesia.

\subsection{Population and Sample}

The population of this study were all medical students at Faculty of Medicine, Al-Azhar Islamic University, Mataram, West Nusa Tenggara, Indonesia. A total of 260 medical students were participated in this study by simple random sampling.

\subsection{Study Variables}

The dependent variable in this study was online learning satisfaction. Independent variables were knowledge, attitude, and perception.

\subsection{Study Instruments}

The data for this study was gathered using a Google form and an online questionnaire. Participants were encouraged but not compelled to participate. The informed consent was described on the first page of the Google form description before the question page. The link to the Google form was shared through a WhatsApp group. The questionnaire was made from 5 questions about knowledge, 8 questions about attitude, 15 questions about perception, and 10 questions about student's satisfaction. The information was gathered using a set of closed-item questionnaires with five Likert Scale options. The data was gathered using a set of closed-item questionnaires with five Likert Scale options. 1 meant "strongly disagree," 2 meant "disagree," 3 meant "neutral," 4 meant "agree," and 5 meant "strongly agree."

\subsection{Data Analysis}

The data obtained for this study was a self-reported data, collected using online questionnaire (google form). The data were analyzed using multivariate analysis (logistic regression). The data were analyzed using STATA program $13^{\text {th }}$ version.

\subsection{Research Ethics}

This study was conducted using ethical clearance from Ethics Committee of the Faculty of Medicine, AlAzhar Islamic University with number: 30 / EC / FK-06 / UNIZAR / VIII / 2020.

\section{RESULTS}

The results of logistic regression can be showed in Table 1. Based on the results, it can be explained that positive student satisfaction was influenced by students' knowledge, attitudes, and perception about online learning.

Table 1. The results of logistic regression analysis

\begin{tabular}{|l|c|c|c|c|}
\hline \multirow{2}{*}{ Positive Student's satisfaction } & \multirow{2}{*}{ OR } & \multicolumn{2}{|c|}{$95 \% \mathrm{CI}$} & \multirow{2}{*}{$\mathrm{p}$} \\
\cline { 3 - 5 } & & Lower & Upper & \\
\hline Knowledge (high) & 1.94 & 1.07 & 3.51 & 0.029 \\
\hline Attitude (positive) & 1.96 & 1.08 & 3.55 & 0.026 \\
\hline Perception (positive) & 7.02 & 3.90 & 12.63 & $<0.001$ \\
\hline N Observation = 260 & \\
\hline Log Likelihood = -124.10 & \\
\hline $\mathrm{R} 2=0.26$ & \\
\hline $\mathrm{p}<0.001$ &
\end{tabular}

This study reported that there was a relationship between knowledge and student's satisfaction. Students with high knowledge had the possibility of having positive satisfaction 1.94 units higher than students with low knowledge $(\mathrm{OR}=1.94 ; 95 \% \mathrm{CI}=1.07$ to $3.51 ; \mathrm{p}=$ 0.029).

There was a relationship between attitude and student's satisfaction. Students with a positive attitude have the possibility of having positive satisfaction 1.96 units higher than students with low knowledge (OR = $1.96 ; 95 \% \mathrm{CI}=1.08$ to $3.55 ; \mathrm{p}=0.026$ ).
There was a relationship between perception and student's satisfaction. Students with positive perceptions had a probability of having positive satisfaction 7.02 units higher than students with negative perceptions (OR $=7.02 ; 95 \% \mathrm{CI}=3.90$ to $12.63 ; \mathrm{p}<0.001)$.

\section{DiscuSSION}

This study reported that high knowledge $(\mathrm{OR}=1.94$; $95 \% \mathrm{CI}=1.07$ to $3.51 ; \mathrm{p}=0.029)$, positive attitude $(\mathrm{OR}=1.96 ; 95 \% \mathrm{CI}=1.08$ to $3.55 ; \mathrm{p}=0.026)$, and positive perception $(\mathrm{OR}=7.02 ; 95 \% \mathrm{CI}=3.90$ to $12.63 ; \mathrm{p}<0.001)$ 
increased the positive medical student's satisfaction towards online learning during pandemic COVID-19.

Similar study in Japan during COVID-19 pandemic reported that students with a graduate degree or higher had significantly more advanced knowledge, were more willing to accept anxious news, and were slightly more satisfied with online lectures and assignments. Japanese students had a greater understanding of fundamental concepts and were more sensitive to the declaration of an emergency [6].

One of the efforts made by the Faculty of Medicine at the Al-Azhar Islamic University is to use an online learning system. Students and lecturers can be protected from COVID-19 infection by using online learning. In the educational process, online learning can also save time and resources. According to Hartley in Darmawan (2015), online learning is a technique or system in the learning process that utilizes the internet as a medium for delivering teaching materials from teacher to student [7].

The success of the online learning process can be seen from various aspects, one of which is the level of student satisfaction. In this study, it was found that medical student's satisfaction with the new learning system (online learning) was influenced by knowledge, attitudes, and perception.

According to Listiani in Sukesih (2020), knowledge is all the results of human sensing of an object that is obtained through the senses he/she has. The level of someone's knowledge of an object varies depending on the results of sensing each person. Attitude is a closed response or reaction from a person to a stimulus. Attitude manifestations cannot be seen directly, but can only be interpreted from one's closed behavior. In addition, attitudes have three components, namely cognitive, affective and behavioral / conative [8].

Schacter (2011) reported that perception is the process of recognizing and interpreting sensory information from the nervous system and sense organs. Perception is useful for providing an overview and understanding of the environment. Perception is greatly influenced by the complex nervous system in the human body [9].

From various definitions of knowledge, attitude, and perception, it can be seen that these three things can be influenced by other components. However, in this study components that indirectly or directly affects students' knowledge, attitude, and perception of online learning methods are not involved in data processing. This is an opportunity for further researcher to investigate this issue.
All entities involved in the dynamic learning process may find this study useful as a pedagogical tool. Faculty of medicine must continue to invest in system upgrades so that online learning systems have faster response times, improved accessibility, increased system reliability and flexibility, and ease of use [10].

\section{CONCLUSION}

Medical student's satisfaction in online learning during pandemic COVID-19 increases by high knowledge, positive attitude, and positive perception. Further study is needed to asses more factors that contribute to medical student's satisfaction toward online learning and to improve quality of the data more than just a self-reporting questionnaire.

\section{AUTHORS' CONTRIBUTION}

Artha Budi Susila Duarsa, Dina Qurratu Ainin, and Dasti Anditiarina designed the study concept, analyzed the data, made the results and discussion, and prepared the manuscript.

\section{ACKNOWLEDGMENTS}

All authors are thankful for the Faculty of Medicine, Al-Azhar Islamic University who provide the facility and fund for this study.

\section{REFERENCES}

[1] Peraturan Pemerintah No 21 Tahun 2020 tentang Pembatasan Sosial Berskala Besar (PSBB)

[2] Surtikanti, M.W. Textbook Evaluation on Curriculum 2013-Based Textbook "When English Rings A Bell" for the Seventh Grade. Journal of English Education and Literature (2020). 1(1), 11 17

[3] Basid A., Rosmaiyadi, Triani S.N., Fitri. Investigation of Online Learning Satisfaction During COVID 19: In Relation to Academic Achievement (2020). Vol 6 (3). DOI: https://doi.org/10.26858/est.v1i1.14803

[4] Mayer, R. E. Thirty years of research on online learning. Applied Cognitive Psychology, (2018). 33(2), 152-159. https://doi.org/10.1002/acp.3482

[5] Noetel, M., Griffith, S., Delaney, O., Sanders, T., Parker, P., del Pozo Cruz, B., \& Lonsdale, C. Are you better on YouTube? A systematic review of the effects of video on learning in higher education. (2020). https://doi.org/10.31234/osf.io/kynez

[6] Hatabu A, Mao X, Zhou Y, Kawashita N, Wen Z, Ueda M, Takagi T, Tian YS. Knowledge, attitudes, and practices toward COVID-19 among university students in Japan and associated factors: An online cross-sectional survey. PLOS ONE 15(12). (2020). https://doi.org/10.1371/journal.pone.0244350 
[7] Darmawan F. Pengukuran Tingkat Kepuasan Pemanfaatan E-Learning. J Speed-Sentra Penelit Eng Dan Edukasi 2015; 7:63-71.

[8] Sukesih, Usman, Budi S, Nur Adkhana Sari D. Pengetahuan dan Sikap Mahasiswa Kesehatan Tentang Pencegahan Covid-19 Di Indonesia. / J Ilmu Keperawatan Dan Kebidanan 2020; 11:410-4.

[9] Schacter D. Psychology. New York: Worth Publishers; 2011.

[10] Saba, T. Implications of E-learning systems and self-efficiency on students' outcomes: a model approach. Hum. Cent. Comput. Inf. Sci. 2, 6 (2012). https://doi.org/10.1186/2192-1962-2-6 